\title{
A Comparative Analysis of the Performance of the Parliamentary Left in the Indian States of Kerala, West Bengal and Tripura
}

\section{Kerem Gabriel Öktem}

To cite this article: Kerem Gabriel Öktem (2012) A Comparative Analysis of the Performance of the Parliamentary Left in the Indian States of Kerala, West Bengal and Tripura, South Asia: Journal of South Asian Studies, 35:2, 306-328, DOI: 10.1080/00856401.2012.667366

To link to this article: http://dx.doi.org/10.1080/00856401.2012.667366

曲 Published online: 04 May 2012.

Submit your article to this journal $\llbracket$

Џ Article views: 224

Q View related articles $\longleftarrow$

Citing articles: 1 View citing articles $\square$ 


\title{
A Comparative Analysis of the Performance of the Parliamentary Left in the Indian States of Kerala, West Bengal and Tripura
}

\author{
Kerem Gabriel Öktem \\ Bilkent University, Ankara
}

\begin{abstract}
This article compares the fortunes of the government coalitions under the leadership of the Communist Party of India (Marxist) or CPI(M) in Kerala, West Bengal and Tripura. The pattern of development and the success of the coalitions differ. In Kerala, the Left has lost every other election, whereas in West Bengal and Tripura, it has won many consecutive elections. West Bengal has seen stagnation in terms of human development, whereas Kerala and Tripura turned - to different degrees - into model states for human development. It is argued that the reasons for these different paths are to be found in the different strategies followed by the regional party units. Developmental success has been delivered through a mobilisation-based approach which has been followed in Kerala and Tripura, but given up in West Bengal. This study explores the three cases and elaborates on the reasons for the choice of strategies in the three states.
\end{abstract}

Keywords: Human development, mobilisation, Left parties, Communist Party of India (Marxist), Indian communism, Kerala, West Bengal, Tripura, Left Front

\section{Introduction}

The three Indian states in which Leftist parties ${ }^{1}$ have been strong both historically and today, Kerala, West Bengal and Tripura, show very different

I would like to thank P.G. Babu, Vikas Kumar and Saime Özçürümez Bölükbaşi for their support in pursuing this work and the two anonymous South Asia reviewers for their valuable comments on the paper.

${ }^{1}$ When talking about Leftist parties here, I refer to the coalitions led by the Communist Party of India (Marxist) or CPI(M) and the first communist ministry in Kerala. Today, there are three Left coalitions: the Left Front in West Bengal and in Tripura and the Left Democratic Front in Kerala. The coalitions are made 
patterns in terms of socio-economic development and in terms of the politics and policies of the Left parties. Why is this so? Why did the paths of these states diverge?

The Left parties first came to power in India in the small south-western state of Kerala in 1957 and, since then, they have usually won every other election in that state against a coalition led by the Congress Party. In the meantime, the reforms the Left has enacted have helped to make the state the most advanced in India in terms of human development. In the big eastern state of West Bengal, the first election victory of the Left was in 1967, but there it initially brought only confrontation and violence and was soon voted out. However in 1977 the Communist Party of India (Marxist) or CPI(M) won the state election in West Bengal and remained in power there until the Assembly election in 2011. In contrast to Kerala, though, it has failed to turn West Bengal into a model state. Also in 1977, a CPI(M)-led government came to power in the tiny north-eastern state of Tripura. There, it was forced out of power in 1988, but elected again in 1993. From then on, its rule has been uninterrupted and its human development policies quite successful.

Even though there has been a lot of research done on Kerala and West Bengal, the fortunes of the Left in these three states have rarely been compared academically. The closest have been studies that have tried to find reasons for the difference between Kerala and West Bengal. ${ }^{2}$ Most importantly, Manali Desai asked 'under what conditions [will] Leftist parties ... carry out important poverty alleviating and equality inducing social reforms'. She argued that 'different historically evolved party formations' were one reason why the party units in these two states implemented different policies. According to Desai, the fact that communists in Kerala 'grew out of a tradition of mass-based, grassroots organization, while the CPI in Bengal was more isolated from

up of different parties in different regions, but their core is the CPI(M). The Communist Party of India (CPI) and the Revolutionary Socialist Party are included in all these coalitions, but they are only minor partners.

${ }^{2}$ P. Eashvaraiah, Communist Parties in Power and Agrarian Reforms (Delhi: Academic Foundation, 1993); Ross Mallick, Indian Communism. Opposition, Collaboration and Institutionalisation (Delhi: Oxford University Press, 1994); and Manali Desai, 'Party Formation, Political Power, and the Capacity for Reform: Comparing Left Parties in Kerala and West Bengal, India', in Social Forces, Vol.80, no.1 (Sept. 2001), pp.37-60. These three either study the general performance of the Left or compare the two states. While Kerala and West Bengal have been extensively studied, the same cannot be said about Tripura. However there has been some more recent work that makes an analysis possible. See Government of Tripura, Tripura Human Development Report 2007 (Agartala: Government of Tripura, 2007); B.G. Verghese, India's Northeast Resurgent-Ethnicity, Insurgency, Governance, Development (New Delhi: Konark, 1996); and Gulshan Sachdeva, Economy of the North-East: Policy, Present Conditions and Future Responsibilities (New Delhi: Konark, 2000). 
popular movements', explained why social reform was far more successfully implemented in Kerala than in West Bengal. ${ }^{3}$

Desai's analysis is insightful, but incomplete. Building on earlier case studies of the three states, this paper complements Desai's framework in three dimensions. Firstly, the historical period of analysis is not restricted to the party formation stage, but takes later developments into account as well. This is especially crucial in the case of West Bengal. Secondly, Tripura as a third case is added as a control for 'the presence of Leftist parties in parliamentary democracies' in the analysis of the development of the states. ${ }^{4}$ As the Left is weaker in Kerala than it is in West Bengal, a third case might demonstrate that differences do not necessarily arise from variations in party strength. Thirdly, using Patrick Heller's analysis of the Kerala case, the competitiveness of the political system is taken into account. ${ }^{5}$ Left parties do not act in a politicalinstitutional vacuum, but interact, especially with their competitors, so variations among the states in this respect are crucial for explaining the differences in their developmental success.

Before elaborating on the variations between Kerala, Tripura and West Bengal, two issues need to be clarified: firstly, the concept of development used here requires explanation. Understanding development in classical terms - as economic development-would yield a different result than applying the more sophisticated human development concept proposed by Amartya Sen. The aim of the capability approach, which is at the heart of the idea of human development, is to evaluate a person's advantage in terms of his 'actual ability to achieve various valuable functionings'. ${ }^{6}$ As functionings are defined as the various things a person manages to do or be, one could describe it as an evaluation of the ability of any person to reach the valuable state of being or to perform valuable acts. The capability approach can also be used on an aggregate level to assess the impact of policies on a group of people. Underlying the approach is a view of life as a mixture of being and doing, which can offer a more holistic understanding of quality of life and which usually translates into a view of development as a process of expanding people's capabilities. This concept is operationalised through diverse indicators of the economy, health

\footnotetext{
${ }^{3}$ Desai, 'Party Formation, Political Power, and the Capacity for Reform', pp.38-40.

${ }^{4}$ Ibid.

${ }^{5}$ Patrick Heller, 'Degrees of Democracy, Some Comparative Lessons From India', in World Politics, Vol.52, no.4 (July 2000), pp.484-519.

${ }^{6}$ Amartya Sen, 'Capability and Well-Being', in Martha Nussbaum and Amartya Sen (eds), The Quality of Life (New York: Oxford University Press, 1993), pp.30-54. For further discussion, see Amartya Sen, Development as Freedom (Oxford: Oxford University Press, 1999).
} 
and education, out of which the Human Development Index (HDI) can be formed. ${ }^{7}$

The second issue to be clarified is the state of the communist movement in India. This is important because we have to understand the objectives of the movement, especially while leading state governments, in particular its policy priorities and views on development, to compare them in a meaningful way. The main actors in the state governments under scrutiny in Kerala, West Bengal and Tripura are the Communist Party of India (CPI) and the CPI(M).

\section{Parliamentary Communism in India: The CPI and the CPI(M)}

For a long time, the CPI struggled with a basic strategic question-how to relate itself to the nationalist movement led by the Indian National Congress (INC). While one faction of the CPI wanted to support the progressive part of Congress, another faction could find no common ground with the INC because it saw Congress as representing the interests of the evolving bourgeoisie in urban areas, and of large landowners in rural areas. ${ }^{8}$ The faction supporting collaboration with the INC eventually achieved hegemony in the CPI, and so the party supported the independence movement during the 1940s and Jawaharlal Nehru's socialist rhetoric in the early years after independence. ${ }^{9}$

In the aftermath of the Sino-Indian War of 1962, the CPI split into two factions, Leftist-centrists and Rightists. The Leftists supported a more revolutionary, anti-Congress strategy while the aim of the Rightists was to support progressive tendencies in Congress. The centrists were divided on the question of which group to join, but eventually allied themselves with the Leftists to form the Communist Party of India (Marxist). ${ }^{10}$ For a while, the two parties opposed each other in elections. The CPI supported Congress and, later, Congress(I), Indira Gandhi's faction, whereas the CPI(M) took part in

\footnotetext{
${ }^{7}$ United Nations Development Programme, Human Development Report 1995 (New York: Oxford University Press, 1995), pp.11-23.

${ }^{8}$ See Irfan Habib, 'The Left and the National Movement', in Social Scientist, Vol.26, nos.5/6 (May-June 1998), pp.3-33, for the history of the CPI until 1947. The rest of the paper draws mainly on Eashvaraiah, Communist Parties in Power and Agrarian Reforms for the pre-1964 era and Mallick, Indian Communism, for the post-1964 era.

${ }^{9}$ Interestingly, some Leftists chose to work within Congress as a faction called the Congress Socialist Party. In Kerala, the communist movement evolved out of this faction of Congress.

${ }^{10}$ On another level, the split was also because of differences over the Sino-Soviet dispute. The Leftists took the Chinese Communist Party as their role model and aimed at creating some sort of peasant revolution, whereas the Rightists were close to the Soviet Union and, thus, the Comintern line.
} 
anti-Congress coalitions, including some with the Janata Party, the first major 'centrist alternative to the Congress Party'. ${ }^{11}$

Another split in the CPI(M) occurred in 1969. Dissatisfied with the results of the parliamentary struggle so far and inspired by the Naxalbari uprising, the Maoist faction decided to pursue extra-parliamentary action. This helped the centrists in the $\mathrm{CPI}(\mathrm{M})$ (which slowly became the main parliamentary communist party) become stronger and, increasingly, it was they who decided the party line. The pro-Congress CPI, on the other hand, tried to push Congress in a more progressive direction. Following the split of the Congress Party in 1969, the CPI supported the faction led by Indira Gandhi. This put it in a difficult position during the Emergency (1975-77), when it continued to support Indira Gandhi's authoritarian rule. ${ }^{12}$ Voters did not approve and so the CPI became largely insignificant following the 1977 election, which the Janata Party won so decisively. ${ }^{13}$

During the Emergency, the CPI(M) was largely underground and silent, but it never allied itself with Indira Gandhi. This helped it to return to power in the West Bengal state election held in the aftermath of the Emergency. Although it did not have to ally itself with any 'bourgeois' party to govern, the CPI(M) maintained relatively moderate policies while in power. It was in 1977 that the CPI(M) finally became reformist: however rather than confront the institutions of the Indian republic, it tried to change the socio-economic situation within the state. This strategy essentially meant a break from its earlier confrontational tactics. Previously the communists had relied on mass mobilisation to force social change at ground level, irrespective of any constitutional constraints. These radical tactics had made the more moderate allies of the Left nervous and thus undermined the coalition governments led by the Left. After 1977, the tactics of the Left softened, as we will see below.

Since 1977, the reformist stance of the CPI(M) has remained more or less unchanged. As Atul Kohli notes, it is 'a party that is communist in name and organization but "social democratic" in ideology and practice'. ${ }^{14}$ Its defining

\footnotetext{
${ }^{11}$ Robert L. Hardgrave Jr. and Stanley A. Kochanek, India: Government and Politics in a Developing Nation (Boston: Thomson, 7th ed. 2008), p.315.

${ }^{12}$ Cf. Ouseph Varkey, 'The CPI-Congress Alliance in India', in Asian Survey, Vol.XIX, no.9 (Sept. 1979), pp.881-95.

${ }^{13}$ For the Left's election results, see the website of the Election Commission of India [http://eci.nic.in, accessed 7 June 2011].

${ }^{14}$ Atul Kohli, The State and Poverty in India. The Politics of Reform (Cambridge: Cambridge University Press, 1987), p.7.
} 
political stance in national terms is its opposition to communal politics, unregulated economic globalisation, and imperialism. However the policies of the CPI(M) differ from state to state. Many see the West Bengal unit, for example, as fostering economic globalisation because of its attempts to create special economic zones in rural areas. Moreover, as Desai argues, the 'ostensibly common identity of the Communist Party of India conceals different historically evolved party formations'. ${ }^{15}$ In Kerala, it 'grew out of a tradition of mass-based, grassroots organization, while the CPI in Bengal was more isolated from popular movements,, ${ }^{16}$ and in Tripura, it developed a symbiotic relationship with the literacy movement. ${ }^{17}$ According to Desai, these specific party formations have each played a role in shaping the policies of the Left in these states, but as the analysis below shows, it is insufficient to restrict oneself merely to the period of party formation.

Parliamentary communist parties in different states have differed in their attitudes towards development. Firstly, it should be noted that, especially prior to 1977 , development was considered to be a secondary issue. The primary aim of the communist parties was to bring about a revolution. Development was important only insofar as it served this aim and it was not until later, with the rise of reformism, that development became important, with the policies of the Left either aimed at bringing about development or impacting upon it.

Generally, Left parties found it difficult to achieve substantial economic development - in particular, industrialisation - within a capitalist framework. Capital would not invest in regions with comparatively strong labour regulations, a politicised labour force, or state governments that they perceived to be hostile. This in turn may have been why the communist parties in power focused on other issues such as land reform, decentralisation and education. It also explains why their work on the development front can be much better analysed using the concept of human development. ${ }^{18}$

\footnotetext{
${ }^{15}$ Desai, 'Party Formation, Political Power, and the Capacity for Reform', p.39.

${ }^{16}$ Ibid., p.40.

${ }^{17}$ Harihar Bhattacharyya, 'Communism, Nationalism and Tribal Question in Tripura', in Economic and Political Weekly, Vol.XXV, no.39 (29 Sept. 1990).

${ }^{18}$ Interestingly, Pedersen analyses the CPI(M) in West Bengal in the framework of embedded autonomy. See Jorgen Dige Pedersen, 'India's Industrial Dilemmas in West Bengal', in Asian Survey, Vol.XLI, no.4 (JulyAug. 2001), pp.646-68; and Peter Evans, Embedded Autonomy: States and Industrial Transformation (Princeton, NJ: Princeton University Press, 1995). The Left's links with trade unions are a substitute for its lack of links with business. However, even though Pedersen sees it as a case of embedded autonomy, the developmental results do not fit the prediction of the theory. A similar attempt was made by Peter Evans for the case of Kerala (Evans, Embedded Autonomy, pp.235-40). I have disregarded this framework in my analysis for two reasons. Firstly, it focuses too narrowly on economic development - a problem Evans also notes in his discussion of Kerala. His recent work assumes a more complex understanding of development,
} 
Generally, the Left has aimed to achieve development by introducing substantive change on the ground, often by introducing policies of a redistributive nature, which require strong mobilisation. Thomas Isaac argues in the context of the People's Planning Campaign in Kerala that '[f]undamental reforms cannot be merely legislated. Legislation remains empty phrases unless powerful movements oversee their implementation'. ${ }^{19}$ This is as true for this reform as it is for other Leftist projects such as Operation Barga, an initiative to ameliorate the poor situation of sharecroppers in West Bengal during the 1970s.

To conclude these introductory notes and to shift our attention to the case studies: the Left has ruled in different times, in different states, in different coalitions. Despite these substantial variations, we can identify with respect to developmental progress a way of conducting politics that has accompanied the successful initiatives of the Left in all these state governments. Hence, our focus in the analysis of the Left in Kerala, West Bengal and Tripura will be on its ability to change realities on the ground through mobilisation.

\section{The Case of Kerala}

A lot has been written about development in Kerala. This is unsurprising given its extraordinary trajectory, which couples very high levels of human development with low per capita income. The literature, of course, searches for reasons for this distinct way of development, identifying the redistributive reforms of the Left Front governments as an important factor. ${ }^{20}$ In the context

\footnotetext{
but I am not (yet) convinced that it is suited to grasping the unconventional path of the CPI(M)-governed states. See Peter Evans, 'In Search of the 21st Century Development State', Working Paper no.4, Centre for Global Political Economy (Dec. 2008). Secondly, Evans' framework emphasises the role of the bureaucracya variable I implicitly assume to be more or less constant across the three cases and, thus, playing no role in explaining the different outcomes in them.

${ }_{19}^{19}$ T.M. Thomas Isaac, 'Campaign for Democratic Decentralisation in Kerala', in Social Scientist, Vol.29, nos.9/10 (Sept.-Oct. 2001), p.9.

${ }^{20}$ For an overview of the scholarly perspectives on the Kerala model, see T.M. Thomas Isaac and P.K. Michael Tharakan, 'Kerala: The Emerging Perspectives: Overview of the International Congress on Kerala Studies', in Social Scientist, Vol.23, nos.1/3 (Jan.-Mar. 1995), pp.3-36. For differing perspectives on the causes of the success of Kerala, see G. Parayil, 'The "Kerala Model" of Development: Development and Sustainability in the Third World', in Third World Quarterly, Vol.17, no.5 (Dec. 1996), pp.941-57; Heller, 'Degrees of Democracy'; Sen, Development as Freedom; Chennat Gopalakrishnan, 'Culture, Economic Development, and Quality of Life: A Speculative Comment on the Case of Kerala, India', in American Journal of Economics and Sociology, Vol.47, no.4 (Oct. 1988), pp.455-7; and Robin Jeffrey, 'Legacies of Matriliny: The Place of Women and the "Kerala Model", in Pacific Affairs, Vol.77, no.4 (Winter 2004/2005), pp.647-64. The Centre for Development Studies, Kerala Human Development Report 2005 (Thiruvananthapuram: Government of Kerala, 2006) gives an overview of Kerala, its history and state of development.
} 
of our comparison with Tripura and West Bengal, four features of the Kerala case will be focused upon: the first communist ministry in 1957; the failure of the Left to become the dominant political actor; the comparatively less violent nature of Kerala politics; and the issue of decentralisation.

The first communist-led government in India was formed in Kerala in $1957 .{ }^{21}$ It was based on the then-undivided CPI, but also relied on some independent members of the Legislative Assembly. As already mentioned, the main strategy of the CPI at that time was to enforce radical change from below, as far as this was possible, within a liberal-democratic framework. The idea was that if this did not succeed, the contradictions within the political system would sharpen, which would eventually help those forces advocating a change of the system-most importantly, the communists. Radical change was attempted initially in two areas: land reform; and a change in the education system. ${ }^{22}$ Eventually, both attempts were unsuccessful. The land reforms ordinance and the education bill failed to become reality. However on a more subtle level, both were successful: while the state government could not implement them, the issues were put on the table, and important aspects of both were implemented by subsequent governments.

Still, for the first communist government, these initiatives proved fateful. The education bill met heavy opposition from sections of Kerala society, and the plans for land reform to limit the amount of land a person could own were stopped by the Supreme Court. Worse, these attempts at drastic change caused the centre to react. It used Article 356 of the Constitution to dismiss the state government on the grounds that law and order had broken down. This experience was pivotal for the Indian Left as a whole, because it starkly revealed the limits of Indian democracy. Later Indian Leftists would often cite this case as an example of what not to do. At the same time, however, in terms of strategies and outcome, this experience was archetypical for early communist-led governments.

After this experience, at times the Left succeeded in increasing its popular vote share, but never became a dominant political force. This is striking because it contrasts with the experience in West Bengal and Tripura, where the Left has

\footnotetext{
${ }^{21}$ The following narrative relies, among others, on G.K. Lieten, 'Education, Ideology and Politics in Kerala 1957-59', in Social Scientist, Vol.6, no.2 (Sept. 1977), pp.3-21; and G.K. Lieten, 'Progressive State Governments: An Assessment of the First Communist Ministry in Kerala', in Economic and Political Weekly, Vol.XIV, no.1 (6 Jan. 1979), pp.29-39.

${ }^{22}$ For a thorough analysis of the attempts to introduce land reform in Kerala, see Chapter 5 of Eashvaraiah, Communist Parties in Power and Agrarian Reforms.
} 
managed to become the hegemonic actor. In Kerala, the Left has proven itself unable to win two consecutive elections. Those elections it did win were with the help of non-Leftist parties such as the Indian National League, which is seen as partisan because it is Muslim-based. Thus in terms of political success, Kerala is not a model state for the CPI(M) and its allies.

Paradoxically this political failure might be one reason for the state's developmental success: Kerala's highly-competitive political environment may have been conducive to its better developmental performance. ${ }^{23}$ Consider the problem of corruption, which is endemic in India. Electoral competitition makes it more important for the party in power to control corruption, or it will be voted out of power. On the other hand, if both competing parties are corrupt, the problem will persist. Earlier however, especially during the first communist ministry, the communists proclaimed an anti-corruption agenda and were perceived as honest. This put Congress in a difficult position, as a perceived increase in corruption during its term in power would almost surely translate into it losing votes in the next election. Then again, the communists might be seen as honest, but this could change once the means of being corrupt - that is, constant power - were established. It may be that the ongoing stiff competition from Congress has helped the Left avoid this pitfall in Kerala.

How much does this rational actor-based model apply to Kerala? Generally, we have to be careful to not see (Indian) politics as more rational than they actually are. But at the same time, it is difficult to dismiss the model completely; most probably there will be differences between a situation in which there is a constant power struggle, and one in which there is consecutive single-party rule. Similarly, there should be a difference between competition involving disciplined, issue-based parties and competition involving non-issue-based, undisciplined parties, or, in Kaare Strom's terms, competition involving policyseeking parties and competition involving office-seeking parties. ${ }^{24}$

Three other ways in which electoral competitiveness might have helped Kerala can be extrapolated from the communists' 1957 experience. Firstly, as noted, the Left could not enact its reforms, but it did bring to the fore important issues which were aimed at empowering the marginalised sections of society. Thus the Left was seen as a pro-poor force. In a politicised state such as Kerala, where comparatively large sections of the poor are educated, a Congress-led

\footnotetext{
${ }^{23}$ Heller, 'Degrees of Democracy', develops a similar argument.

${ }^{24}$ Kaare Strom, 'A Behavioral Theory of Competitive Political Parties', in American Journal of Political Science, Vol.34, no.2 (May 1990), pp.565-98.
} 
government could no longer easily turn a blind eye to the problems of the poor. Even when the government was Congress-led, it could not govern with an antipoor agenda. ${ }^{25}$

Secondly, and most importantly for our theoretical framework, when a Congress alliance is in power, the Left is in opposition. Heller describes the effect of this situation in the following way: 'The Kerala CPM's critical role has been less a function of its governance capacity than of its mobilizational capacity. Having found itself periodically in the opposition, the CPM has retained much of the social movement dynamic from which it was born by having to continually reinvigorate its mobilizational base and reinvent its political agenda' ${ }^{26}$ In other words the success of the Left with respect to human development has been dependent on its mobilisational power. Naturally, it has been easier to retain this dynamic in opposition.

Thirdly, it may have been a good thing that the reforms the communists envisaged were not enacted. The reforms might not have been conducive to development, for whatever reason; or they could have led to a counter-reaction from well-off sections of society, leading to large-scale confrontation and violence. Luckily this did not happen, which brings us to the third important aspect of the Kerala case - the adherence to constitutional means in the struggle for political power. By and large, the state has seen very low levels of political violence, which makes it different from the other Indian states. This is even more striking considering its high level of politicisation. As we will see, both West Bengal and Tripura have been marred by political violence. How can we explain this difference? The most promising answer seems to lie in the culture of education in the state. Kerala has always had a comparatively educated population and, following Seymour Lipset, we may suggest that this has helped to keep struggles within constitutional limits. ${ }^{27}$

The last aspect to be emphasised in the Kerala case concerns policy priorities. Whereas land reform was in some way or another always on the agenda of the communists and education was a priority issue for the Kerala Left, the issue of decentralisation was rather neglected. Only in 1996, roughly two decades after

\footnotetext{
${ }^{25}$ Heller, 'Degrees of Democracy', p.508.

${ }^{26}$ Ibid., p.510.

${ }^{27}$ Seymour Martin Lipset, 'Some Social Requisites of Democracy: Economic Development and Political Legitimacy', in The American Political Science Review, Vol.53, no.1 (Mar. 1959), pp.69-105, argues: 'Education... broadens men's outlooks, enables them to understand the need for norms of tolerance, restrains them from adhering to extremist... doctrines, and increases their capacity to make rational electoral choices' (p.79).
} 
the issue was tackled in West Bengal and Tripura, did the Left Democratic Front in Kerala enact the People's Campaign for Decentralized Planning, a comprehensive decentralisation programme. The idea was to swiftly institutionalise decentralisation, implementing it via a campaign to mobilise society. Even though the programme had its problems-particularly that local governments had difficulty in spending the funds earmarked for the campaign - it brought a new dynamic to the process of development, as evidenced in the renewed rise in Kerala's literacy rate. ${ }^{28}$

Summarising the Kerala experience, we can conclude that the presence of the Left has been a success in terms of the policies it implemented and the

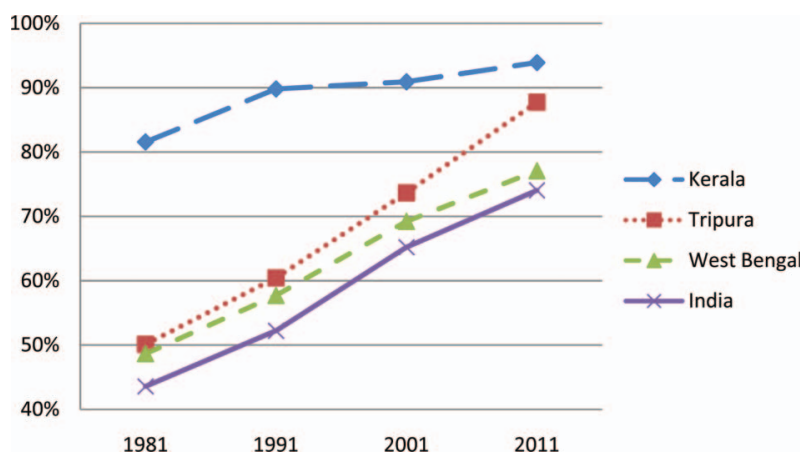

\section{Figure 1}

\section{Literacy Rates}

Source: Government of India, Planning Commission, National Human Development Report 2001 (New Delhi: Government of India, 2002), p.186, and Government of India, Census of India: Provisional Population Totals, Paper 1 of 2011, India Series 1 (New Delhi: Office of the Registrar General \& Census Commissioner India, 2011), p.113.

\footnotetext{
${ }^{28}$ Data on literacy rates (proportion of literates to the population in the age group over seven) are from Government of India, Planning Commission, National Human Development Report 2001 (New Delhi: Government of India, 2002), p.186, and Government of India, Census of India: Provisional Population Totals, Paper 1 of 2011, India Series 1 (New Delhi: Office of the Registrar General and Census Commissioner India, 2011), p.113 [http://www.censusindia.gov.in, accessed 3 June 2011]. Relevant statistics confirm that decentralisation has been a success. See Government of India, Planning Commission, National Human Development Report 2001; and Centre for Development Studies, Kerala Human Development Report 2005. For critical assessments of the People's Planning Campaign, see M.K. Das, 'Kerala's Decentralised Planning: Floundering Experiment', in Economic and Political Weekly, Vol.XXXV, no.49 (2 Dec. 2000), pp.4300-3; Richard W. Franke, 'Local Planning: The Kerala Experiment', paper presented at the Left Forum, Cooper Union, New York, 15 Mar. 2008; Thomas Isaac, 'Campaign for Democratic Decentralisation in Kerala'; and Rajan Gurukkal, 'When a Coalition of Conflicting Interests Decentralises: A Theoretical Critique of Decentralisation Politics in Kerala', in Social Scientist, Vol.29, nos.9/10 (Sept.-Oct. 2001), pp.60-76.
} 
developmental progress it brought. At the same time, from a political perspective, Kerala has been disappointing for the Left, as the party failed to become the dominant force and never won consecutive state elections. This pattern contrasts sharply with its experience in West Bengal.

\section{The Case of West Bengal}

In West Bengal, the history of the parliamentary Left can be divided into two periods, pre- and post-1977. The pre-1977 period was marked by confrontation, instability and violence, whereas the later period has been characterised by political stability but developmental stagnation. This second period ended with the state election of 2011 that brought the opposition Trinamool Congress to power, but it is too early to evaluate the Left in this possible third period.

The first communist-dominated state government in West Bengal was formed in 1967, ten years after the first communist ministry in Kerala. ${ }^{29}$ In this government, formed under the United Front, the Left was not as strong as it had been in Kerala ten years before. The CPI(M) had to ally with moderate parties such as the Bangla Congress, which did not have a consistent social reform agenda. Ruling during a food crisis, the coalition was not able to mould its diverse interests into a coherent policy and seemed to have no future. The centre repeated the strategy it had used to unseat the government in Kerala in 1959. It used the governor to dislodge the state government after only six months in power. An alternative government formed at the end of 1967 lasted only about a hundred days, then President's rule was imposed for a year. The central government's interference was very unpopular with Bengali voters, and so the United Front won the election in 1969.

This time, the CPI(M) was stronger and more assertive, and attempted radical land reform from below. Occupation of illegally-owned land by the landless was actively encouraged by the government. This caused resistance from large landowners, the dominant class in rural Bengal. As well, in the aftermath of the Naxalbari uprising in the northern part of the state, the Maoists broke away from the CPI(M) to take up arms. Violence became widespread. After one year in power, the moderate partners of the CPI(M) resigned and President's rule was imposed once again. This marked the beginning of a seven-year period in opposition for the Left. The 1972 election was allegedly rigged by Congress,

\footnotetext{
${ }^{29}$ This part relies mostly on the detailed analysis of the early CPI(M) experiences in power in West Bengal by Mallick, Indian Communism. For attempts at rural reforms, see Eashvaraiah, Communist Parties in Power and Agrarian Reforms.
} 
and between 1975 and 1977 the Emergency curtailed political activity. As elsewhere, in West Bengal the CPI(M) remained largely underground during this period.

Surprisingly, though, it won a landslide victory in the election immediately after the Emergency in 1977. This time, it formed government only with other Left parties under a Left Front umbrella. Defying the expectations of many, this time the Left was much more moderate than before. While in previous governments it had not had any real chance of carrying out its radical reforms, this time, although it took some bold initiatives to begin with, they were less radical than before. Instead of focusing on the most marginalised section of rural Bengal society through comprehensive land reform, the Left Front tried to ameliorate the poor conditions of share-croppers. ${ }^{30}$

On paper, share-croppers did have some rights, such as a guaranteed share of their output, but in practice most were not registered as share-croppers and so could not demand their rights. As a result, they were entirely dependent on the generosity of the landlord whose land they cultivated. Operation Barga, initiated by the Left Front, fundamentally changed this situation. Sharecroppers no longer had to prove they were share-croppers; instead, landlords had to disprove that share-croppers cultivated the land whose produce they laid claim to. This legal change, together with party-led mobilisation, encouraged share-croppers to register their labour to gain their legal rights.

Another important early initiative of the Left Front government was the drive towards decentralisation. ${ }^{31}$ Elections for local governments (panchayats) were first held in 1978, earlier than in any other major state, and have been held regularly ever since. Moreover, far from becoming merely an instrument of the dominant rural classes, many poor peasants and middle-class people have been elected to the panchayats, breaking the traditional dominance of the landlords. However, because the Left Front has easily won most local elections, the

\footnotetext{
${ }^{30}$ See Government of West Bengal Development and Planning Department, West Bengal Human Development Report 2004 (Kolkata: Government of West Bengal Development and Planning Department, 2004), pp.25-42; Kohli, The State and Poverty in India; and D. Bandyopadhyay, 'Land Reforms and Agriculture: The West Bengal Experience', in Economic and Political Weekly, Vol.XXXVIII, no.9 (1 Mar. 2003), pp.879-84.

${ }^{31}$ See Government of West Bengal, Development and Planning Department, West Bengal Human Development Report 2004, pp.43-70; Kohli, The State and Poverty in India; Poromesh Acharya, 'Panchayats and Left Politics in West Bengal', in Economic and Political Weekly, Vol.XXVIII, no.22 (29 May 1993), pp.1080-2; and Maitreesh Ghatak and Maitreya Ghatak, 'Recent Reforms in the Panchayat System in West Bengal: Toward Greater Participatory Governance?', in Economic and Political Weekly, Vol.XXXVII, no.1 (5 Jan. 2002), pp.45-58.
} 
Panchayati Raj system is seen by critics as an instrument of the ruling parties. Even worse is the fact that in thirty years of decentralised governance, the system has failed to bring about substantial change in the level of development as compared to the rest of India, as the chart below on infant mortality shows. $^{32}$

These two bold reforms, Panchayati Raj and Operation Barga, were both passed in the late 1970s. ${ }^{33}$ While they were partially successful in enhancing the situation of a marginalised section of rural Bengali society and of improving rural development, no further initiatives have followed. The promise of change through which the Left Front came to power has not materialised. Instead, its rule has become institutionalised.

Several reasons can be given for this failure. From an electoral perspective, Operation Barga was sufficient to secure the support of a large part of the rural

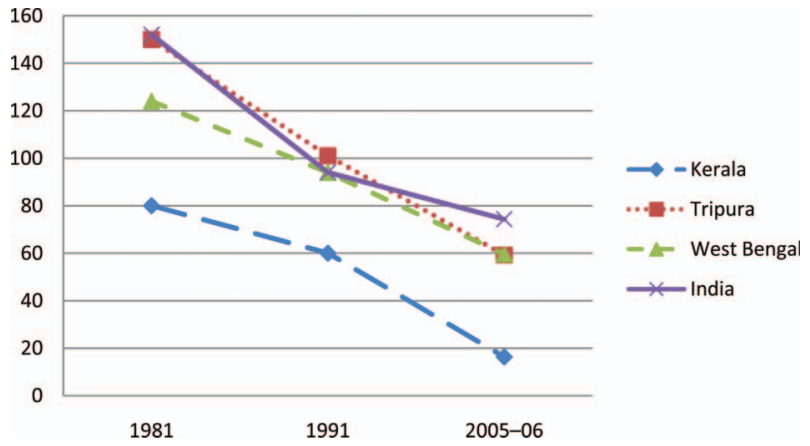

\section{Figure 2}

\section{Under-Five Mortality Rate (per thousand)}

Source: Government of India, Planning Commission, National Human Development Report 2001 (New Delhi: Government of India, 2002), p.228; and International Institute for Population Sciences (IIPS) and Macro International, National Family Health Survey-3 (NFHS-3), 2005-06: India: Vol.I (Mumbai: IIPS, 2007), p.187.

\footnotetext{
${ }^{32}$ Another indication of stagnation is that West Bengal's Human Development Index ranking among the 32 states and union territories of India has changed only marginally over time (Government of India, Planning Commission, National Human Development Report 2001).

${ }^{33}$ Panchayati Raj was a central government initiative, but the timing and depth of its implementation varied widely according to the policies of the respective state governments, with West Bengal being usually cited as a pioneer state in this regard. See Pranab Bardhan and Dilip Mookherjee, 'Land Reform, Decentralized Governance, and Rural Development in West Bengal', paper prepared for the Stanford Center for International Development Conference on Challenges of Economic Policy Reform in Asia (31 May-3 June 2006); and Ghatak and Ghatak, 'Recent Reforms in the Panchayat System in West Bengal'.
} 
population; share-croppers would overwhelmingly vote for the Left Front, which had brought about such a big improvement in their lives. Besides, after 1977, the support base of the CPI(M) changed-no longer did it focus on the poorest of the poor. Instead, the middle-class peasantry became its main support base in rural areas. Because the middle-class peasantry was against radical reforms that would improve the situation of the marginalised at its expense, comprehensive land reform was no longer pursued by the Left Front government.

This change in the party's focus was partly a side-effect of decentralisation reform. When the CPI(M) came to power in 1977, it had 33,000 mostly dedicated members. When local elections were held in 1978, it fielded around 56,000 candidates. ${ }^{34}$ In other words, it had to rely on standing sympathisers and opportunists to win the local election. Candidates who seized the opportunity to get elected on the ruling party's ticket were seldom dedicated Marxists. The party managed to overcome this problem in the course of time. By 1983, it had roughly 100,000 members and, five years later, more than 150,000. This five-fold increase in membership brought another change with it: the party itself became less disciplined and less radical in the course of broadening its membership. ${ }^{35}$

While the party's size is still relatively small in comparison with the size of the electorate, it must also be said that radical reforms, such as the seizure of land by the United Front government in the name of land reform, were achieved with a far smaller party. Paradoxically, in the 1960s members were more dedicated and radical, so mass mobilisation of the poor was still possible. Thus becoming a larger party is one of the reasons why the CPI(M)-led governments have not continued with their mobilisation-based strategy.

Another factor is that many of the most dedicated CPI(M) members left the party following the Maoist split in 1969, and were replaced by more moderate new members. What is more, for the most part these more radical cadres split from the CPI(M) as a result of the mobilisation-based tactics. These tactics entailed a constant need for a radical outlook, cultivated and continued by ground-level cadres. Perceiving the party as not being radical enough, many of these ground-level cadres left to become part of the Maoist uprising. Leaders of

\footnotetext{
34 Acharya, 'Panchayats and Left Politics in West Bengal', p.1080.

${ }^{35}$ Figures for the party's size are taken from Kohli, The State and Poverty in India, p.102; and Mallick, Indian Communism, pp.182-210. In 2008 the party had a membership of more than 320,000 in West Bengal. See CPI(M), 19th Congress Political-Organisational Report 2008 [http://www.cpim.org, accessed 3 Jan. 2010].
} 
the CPI(M) probably feared that this traumatic experience, when many of its best men left the party in order to fight against it, would be repeated if radical, mobilisation-based tactics were continued. We may conclude that the Left Front did not introduce further bold reforms because of its institutionalisation in power and its refraining from mass mobilisation. The poor performance of the opposition and the success of Operation Barga has meant that the electoral imperative to perform better has become practically non-existent.

In the 2000s, the Left Front changed its focus from rural development to industrialisation, following the recent example of the Chinese Communist Party. The earlier concentration on rural development, together with poor state-capital relations, did not bode well for the industrial sector. The state government was unable to reconcile itself to the private sector's reluctance to invest in West Bengal, and it blamed a hostile central government for the resultant industrial stagnation. ${ }^{36}$

In order to overcome this problem, the Left Front tried to attract capital by creating special economic zones in rural areas. These zones were created by buying land from farmers. This is similar to what has been done in other Indian states, but the resistance to it - from the local population, opposition groups and Maoists - has been stronger in West Bengal. In Nandigram, where farmers expected the government to create a special economic zone, a parallel administration was instead established in 2007 to oversee it, and state government officials were not even allowed to enter. Instead of taking the fears of the local population seriously, the Left Front government saw it as a conspiracy by the Maoists and the opposition, led by the Trinamool Congress. It deployed police to retake the area, which they did heavy-handedly, and many people were killed. Similar events occurred in Singur. ${ }^{37}$ Furthermore, from the mid-2000s onwards, the Maoist insurgency in West Bengal accelerated. ${ }^{38}$ In the area of Lalgarh, the Naxalites control large areas of rural land. Rather than trying to understand the socio-economic reasons for the Naxalite resurgence, the Left Front has again approached this problem as one purely of law and

\footnotetext{
${ }^{36}$ See Pedersen, 'India's Industrial Dilemmas in West Bengal'; and Polly Datta, 'The Issue of Discrimination in Indian Federalism in the Post-1977 Politics of West Bengal', in Comparative Studies of South Asia, Africa and the Middle East, Vol.25, no.2 (2005), pp.449-64.

${ }^{37}$ For a detailed analysis of events, see Sumanta Banerjee, 'Moral Betrayal of a Leftist Dream', in Economic and Political Weekly, Vol.XLII, no.14 (7 April 2007), pp.1240-2; Malini Bhattacharya, 'Nandigram and the Question of Development', in Economic and Political Weekly, Vol.XLII, no.21 (26 May 2007), pp.1895-9; and Swapan Dasgupta, 'The Revenge of the Proletariat', in Tehelka Magazine, Vol.6, no.47 (28 Nov. 2009) [http://www.tehelka.com, accessed 7 Mar. 2012].

${ }^{38}$ For details see Dola Mitra, 'Ringed Red Theatre', in Outlook India (7 Sept. 2009) [http:// www.outlookindia.com, accessed 31 Jan. 2012].
} 
order, much as most Naxalite-affected states do, despite an expectation that a Left government would behave differently.

In light of these setbacks, it is no surprise that the CPI(M)-led state government was voted out of power in 2011, after 34 years of continuous rule. The loss stems mainly from the failures of the Left Front government. It won successive elections with great ease, but never set out a radical reform agenda. In the beginning, it launched inspiring initiatives, but then fell into a pattern of stagnation. From the perspective of electoral competition, this experience in West Bengal is as unsurprising as the example of Kerala: more than thirty years of uninterrupted rule does not necessarily make a party perform particularly well. However, the third state in our analysis, Tripura, does not fit into this pattern at all.

\section{The Case of Tripura}

In Tripura, the communist movement developed very differently from those in other parts of India. While during the nationalist struggle, the communists aligned themselves with the Congress-led independence movement, in Tripura communism evolved in synergy with Tripura nationalism. The latter was more a form of regionalism than a nationalism directed against India. Needless to say, regional identities also mattered in Kerala and West Bengal, but the extent to which the communists aligned with the Tripura movement was remarkable. ${ }^{39}$

The primary aim of communism in Tripura was to advance the interests of the indigenous inhabitants of Tripura who, due to the immigration of Bengalis during the last century, had become a minority in their own homeland. ${ }^{40}$ The indigenous inhabitants had become marginalised socio-economically, with less access to education than Bengalis and with their ancestral land having been given to the immigrants. In the late 1940s, the communists even led an unsuccessful armed uprising to achieve their aims. Following this they refrained from violence, but the CPI's failure to take power constitutionally led some tribal people to pursue the path of violence once again, leading to a split between the nationalists and communists in Tripura.

\footnotetext{
${ }^{39}$ To my knowledge, a comparative study of the extent to which communists in other regions, such as Kerala, West Bengal and Andhra Pradesh, used their respective regional identities to gather support, and underwent a change of identity in this process, remains to be conducted. However, the existing evidence points to Tripura communism having a special status in this respect.

${ }^{40}$ See Government of Tripura, Tripura Human Development Report 2007, p.10, for an overview of the indigenous inhabitants of Tripura.
} 
In 1977, the Left Front was voted into power for the first time in Tripura. By that time, the armed insurgency of the Tribal National Volunteers (TNV) had polarised society and the perceived pro-tribal stance of the Left Front led the Bengalis to create their own militia. In 1979, the state government created the Tripura Tribal Areas Autonomous District Council (TTAADC), an autonomous region for the indigenous people of Tripura. The TTAADC covered more than two-thirds of the state and some segments of the Bengali population feared that the TTAADC would mean the end of Tripura as an Indian state. The polarisation worsened to such an extent that in June 1980, riots broke out. ${ }^{41}$ Thus, the first term of the Left Front was marred by conflict.

From an administrative perspective, the TTAADC was a step towards decentralisation, which was paralleled by the introduction of the Panchayati Raj system around the same time. However in such a polarised environment, with an armed insurgency active in many parts of the state, these policies did not have the desired developmental effects. In 1988, the Left Front was voted out of power and the new Congress-led state government made a peace agreement with the insurgents. This agreement failed to bring lasting peace and the disappointed insurgents created new armed groups that continued to fight the state. In 1993, the Left Front again came to power and has remained in government ever since.

The main focus of the Left Front now became to improve education. A literacy campaign targeting both Bengali and tribal adults was started with the support of civil society organisations. Follow-up campaigns were conducted to ensure that the neo-literates would continue to build on their literacy. This mobilisation-based campaign was very successful, and together with the improvements in the education system, it helped raise the state of education in Tripura to a much higher level. ${ }^{42}$

One reason that the Left Front took this road was that its mass support in Tripura was based on the tribal education movements of the 1940s; part of its identity and legitimacy sprang from its focus on education. ${ }^{43}$ Relative to the size of the electorate, the party had many members in Tripura at the time of the new education campaigns. ${ }^{44}$ Another reason was that the tribal insurgency was

\footnotetext{
${ }^{41}$ See Verghese, India's Northeast Resurgent.

${ }^{42}$ Government of Tripura, Tripura Human Development Report 2007, pp.73-85.

${ }^{43}$ See Bhattacharyya, 'Communism, Nationalism and Tribal Question in Tripura'.

${ }^{44}$ The party size:electorate ratio was 1.89 percent in 1998, based on the data of the CPI(M), 17th Congress Political-Organisational Report 2002 [http://www.cpim.org, accessed 4 June 2011]); and of the Election Commission of India [http://eci.nic.in, accessed 7 June 2011].
} 
rooted in the socio-economic marginalisation of the tribals. To end the insurgency, its causes had to be wiped out and education was one of the sectors in which marginalisation was highly visible: in 1981, half of Tripura's population was literate, but only a quarter of tribals could read or write. ${ }^{45}$ Mass mobilisation was used as a strategy because it was one of the CPI(M)'s strengths.

The Left Front continued to fight the insurgency by attacking its root causes. It initiated some symbolic programmes, such as restoring alienated land to the tribals. Even though the material value of this programme might have been negligible, its political value was high. Another initiative has been the re-naming of villages and rivers which were originally named in tribal languages, but had come to be known officially by their Bengali names. This re-naming represented recognition by the government that the land was originally tribal.

These initiatives, together with a counter-insurgency strategy based on the police rather than the army (the former being arguably less heavy-handed than the latter) weakened the insurgent groups and there are indications that the insurgency may end in the near future. ${ }^{46}$ In the meantime, Tripura has advanced markedly in terms of human development. From being a backward state in a backward region, it has become a model state in the field of education ${ }^{47}$ and a positive example of economic turnaround, with per capita income rising from only two-thirds of the national average in the mid 1990s to parity with the all-India level by $2000 .{ }^{48}$ Alas, the same cannot be said about health-related indicators. We can conclude that progress has been stronger than in West Bengal, but more uneven than in Kerala.

\footnotetext{
${ }_{45}$ Government of India, Planning Commission, National Human Development Report 2001.

${ }^{46}$ See Bibhu Prasad Routray, 'Tripura: The Peace Consolidates', in South Asia Intelligence Review, Vol.6, no.31 (11 Feb. 2008) [http://www.satp.org, accessed 7 Mar. 2012]. While this type of counter-insurgency strategy should have helped keep human rights violations low, it must be conceded that the security forces are still responsible for the torturing and killing of civilians. See Asian Centre for Human Rights, India Human Rights Report 2007 [http://www.achrweb.org, accessed 4 Jan. 2010].

${ }^{47}$ To cite just one statistic, the drop-out rate in the elementary stage (Classes I-VIII) has been reduced from 70 percent in 1998-99 to 15 percent in 2007-08. See Government of Tripura, Economic Review of Tripura 2007-08 (Agartala: Government of Tripura Directorate of Economics and \& Statistics Planning (Statistics) Department, 2009).

${ }^{48}$ Computed from Government of India, Ministry of Statistics and Programme Implementation (2008), Statewise SDP with 1993-94 Base Year [http://mospi.nic.in/mospi_nad_main.htm, accessed 2 Jan. 2010]; and Government of India, Ministry of Statistics and Programme Implementation (2010): Statewise SDP with 1999-2000 Base Year [http://mospi.nic.in/mospi_nad_main.htm, accessed 10 June 2011].
} 
Summarising the case of Tripura, it may be said that Left Front rule has been successful, even though the political dominance of the Left resembled West Bengal more closely than Kerala. As in Kerala, the CPI(M)-led government has continued to rely on the mobilisation of society to achieve its goals, although it did not face the same electoral pressure as in Kerala. The reasons for these variations between the states are elaborated in the concluding section.

\section{Conclusion}

The comparison of the three cases of Left rule in India yields interesting results. The success of the Left has been very different in the three states, depending on the capacity for mass mobilisation. This capacity, in turn, was defined by various factors, some of them peculiar to each state.

The competitiveness of the political system is the first factor that needs to be emphasised. In Kerala, a model state in terms of development, there has been far stronger competition for political power than in the other two states. Incumbent governments there hardly ever win elections, so the desire to regain power has served to make them perform better. This is especially visible when contrasting Kerala with West Bengal. In West Bengal, the Left remained in power continuously for 34 years, but after some bold initiatives at first, such as Operation Barga, the development process stagnated. In Kerala, the imperative of remaining competitive has helped the CPI(M) maintain its mobilisational capacity. Despite Tripura having a similar electoral history to West Bengal, the Leftist government there has been much more effective. There, the Left has governed for 29 of the last 34 years and, like West Bengal, it came up with bold projects at the beginning of its rule, such as formation of the TTAADC and its education campaigns. But unlike West Bengal, it has been able to continue its reform momentum. If electoral competition is to be taken as a guide to electoral success, in the last few years in Tripura, when the Left was faced with a weak opposition both in terms of influence and in terms of ideas, it should not have performed well, Yet, it did.

Two other factors might be more revealing in explaining the Tripura experience: policy priorities and party strength. Historically, the priorities in Tripura have been different from those of the other two states. In Tripura, land reform, a crucial issue for the Left in India, has meant giving ancestral land back to the indigenous people. The creation of the TTAADC by the Left Front was part of its land reform agenda. In recent years, the focus has shifted towards ending the insurgency. This was attempted through a multi-pronged approach which tackled the security dimension as well as the roots of the 
insurgency. The marginalised sections of society were socio-economically empowered, the powers of the TTAADC in various fields were strengthened, and the status of the tribals in society was recognised through cultural policies such as giving tribal languages a more prominent place in public life. ${ }^{49}$ The Left Front was not forced into these policies by an opposition on the brink of electoral success as in Kerala, but by a general will to end the insurgency. Another factor that may help to explain the case of Tripura is party strength. In Tripura, the CPI(M) has an extremely high capacity for mobilisation because it has a higher proportion of the electorate as members than in West Bengal or Kerala. According to official figures, the proportion of $\mathrm{CPI}(\mathrm{M})$ party members in the electorates is more than 2.5 percent in Tripura, roughly 1.5 percent in Kerala and only 0.5 percent in West Bengal. ${ }^{50}$

At first glance, it may seem that these numbers do not help to explain the Left's success in Tripura and its failure in West Bengal. The capabilities of the $\mathrm{CPI}(\mathrm{M})$ in organisational terms were simply too low in the latter. However, as noted earlier, the small size of the party is only one aspect of its failure to base politics on mobilisation. The CPI(M) in West Bengal may have a lower membership as a proportion of the electorate, but nevertheless this should be sufficient for a disciplined party to establish a capacity for ground-level reform. Moreover, while membership quadrupled in the first few years of Left rule after 1977, it did not continue along this trajectory. Thus, it appears that the lack of mass mobilisation was a political choice taken by the West Bengal party. The Maoist split was a traumatic experience and it is likely that the party became wary of mass mobilisation.

In that respect, this study extends Manali Desai's analysis of Leftists in West Bengal and Kerala. In her account, the links with the masses during the stage of party formation shaped the later policies of the Leftist governments. Yet, as this paper has shown, this is only part of the story. Firstly, we have seen that the cases of Kerala and West Bengal are not perfectly comparable because the 'presence of Leftist parties in parliamentary democracies', which Desai had

\footnotetext{
${ }^{49}$ See the official website of the Government of Tripura [http://tripura.nic.in/portal, accessed 31 Jan. 2012], and of the TTAADC [http://ttaadc.nic.in, accessed 31 Jan. 2012] for details.

${ }^{50}$ The numbers stated are the average for the state Assembly elections in 2001 and 2006 in Kerala and West Bengal and for 2003 and 2008 in Tripura. Computed from CPI(M), 18th Congress Political-Organisational Report 2005 [http://www.cpim.org, accessed 4 June 2011]; CPI(M), 19th Congress Political-Organisational Report 2006; and the Election Commission of India. For convenience, we focus on party membership here, but it should be kept in mind that membership in unions and other societal organisations is equally, if not more, important.
} 


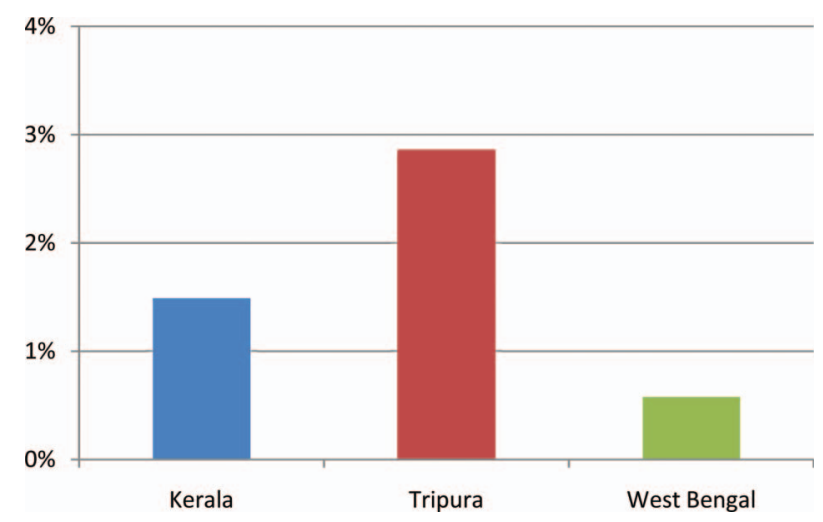

\section{Figure 3}

\section{Members of the $\mathrm{CPI}(\mathrm{M})$ as a Proportion of the Electorate}

Source: Computed from CPI(M), 18th Congress Political-Organisational Report 2005 [http:// www.cpim.org]; CPI(M), 19th Congress Political-Organisational Report 2006; and the Election Commission of India.

sought to control for by comparing the two, is actually lower in Kerala. ${ }^{51}$ Tripura, however, is similar to West Bengal in that the Leftist parties have remained in government continuously for a number of years. Secondly, the experiences in West Bengal, which kept the CPI(M) from pursuing mass mobilisation in the way it did in Kerala and Tripura, did not end at the party formation stage. The Leftist government in West Bengal had the opportunity to establish mass links after regaining power in 1977 but chose not to, probably because of its bitter experience during the 1969 split in the CPI(M) when many low-level cadres chose to join the Maoist insurgency. The consequences of the split were felt far more strongly there than in Kerala or Tripura. This does not mean that Desai's argument should be rejected. On the contrary, the addition of Tripura shows a similarity between it and Kerala. In Tripura, the local communist party was formed and acquired a mass base through its close relationship with the Tripura nationalist movement, which later helped the Left in implementing more substantial reforms when it came to power. Thus, as Desai argues, 'historically developed links' with certain parts of society play a role in making Leftist governments perform well.

\footnotetext{
${ }^{51}$ Desai was trying to control for comparing the two as if they were variables. See Desai, 'Party Formation, Political Power, and the Capacity for Reform', p.38.
} 
However, we have seen that other factors are at least as influential. It is not just the history of the Left parties and their strategies based on mass mobilisation that have shaped their policies, but also the political-institutional context in which they operate. The level of competition for political power, which determines to what degree 'Leftist parties will carry out important poverty alleviating and equality inducing social reforms, ${ }^{52}$ has been shown here to be equally as important.

${ }^{52}$ Ibid. 